\title{
GAYO HIGHLAND TAKENGON FROM 1904 TO 1942: A HISTORICAL ANALYSIS OF COFFEE PLANTATIONS AT THE ERA OF DUTCH COLONIALISM
}

\author{
Sufandi Iswanto ${ }^{1}, \mathrm{Zulfan}^{1}$, Nina Suryana ${ }^{2}$ \\ ${ }^{1}$ Department of History Education, Syiah Kuala University, Banda Aceh \\ ${ }^{2}$ Department of History Education, Jabal Ghafur University, Sigli
}

\begin{abstract}
This article analyzes the history of Coffee Plantations in Gayo Highland Takengon at the time of the Dutch Colonialism era from 1904 to 1942 . This historical research aimed to reveal the social and economic background, history, and the labors' condition of Gayo Highland Takengon Coffee Plantations. The historical method, which consisted of five analytical stages, was used as the method to reconstruct the history of the coffee plantations in Gayo. The findings of the research show that the geographical factors supported Gayo Highland Takengon as the area of the coffee plantation. Coffee was firstly developed at Gayo Highland by Veenhuyzen in 1908. From 1908 to 1918 , coffee was a non-commercial commodity and produced on a small scale. In 1918, after the establishment of Wilhelmina Blang Gele Coffee Plantation and other plantations managed by both private and state companies, coffee increasingly became a commercial commodity. Private and state-owned companies started to employ Javanese laborers or popularly known as Jawa Kontrak and Jawa Kolonisasi. The laborers were brought in gradually from Java and bounded by the Labor System based on the Staatsblad 1911 and Staatsblad 1915. Based on these findings, it can be concluded that the geographical factors and the spirit of capitalism had driven the Dutch private and state companies to develop coffee plantations in Gayo Highland by employing the Javanese contract laborers.
\end{abstract}

Keywords: Gayo Highland, coffee plantation, colonization era.

\begin{abstract}
ABSTRAK
Tulisan ini merupakan kajian tentang analisis historis perkebunan kopi di Dataran Tinggi Gayo Takengon pada era kolonial Belanda (1904-1942). Tujuannya tidak lain untuk mengetahui faktor dibukanya perkebunan, sejarah perkebunan pertama dan buruh yang berkerja pada perkebunan kopi. Metode penelitian yang digunakan adalah metode sejarah dengan menggunakan lima tahapan. Adapun hasil penelitian menunjukkan bahwa secara geografis Dataran Tinggi Gayo cocok dijadikan sebagai kawasan perkebunan kopi, hal tersebut telah mendorong adanya penerapan kapitalisme Barat. Tanaman kopi untuk pertama kalinya dikembangkan di Dataran Tinggi Gayo pada tahun 1908, pelopor pertamamnya seorang Belanda bernama Veenhuyzen. Tanaman kopi tersebut awalnya hanya sebagai tanaman non komersial dengan jumlah terbatas, namun sejak tahun 1918 dengan dibukanya perkebunan kopi Wilhelmina Blang Gele, tanaman kopi menjadi tanaman komersial baik yang dikelola oleh Belanda maupun swasta. Buruh yang diperkerjakan pada perkebunan baik Belanda maupun swasta merupakan buruh kontak orang-orang Jawa yang disebut sebagai Jawa Kontrak dan Jawa Kolonisasi. Para buruh tersebut didatangkan dari Pulau Jawa secara bergelombang dan terikat dengan sistem kontak yang mengacu pada staatsblad tahun 1911 dan staatsblad tahun 1915.
\end{abstract}

Kata kunci: dataran tinggi Gayo, perkebunan kopi, era colonial. 


\section{INTRODUCTION}

At the Dutch colonial era, the plantation business took an essential role in the economic development of the Dutch East Indie. The purposes of the plantation business related to the financial interest and the social and economic wealth of the Dutch by producing surplus from the commodity export (O'Malley, 1988, p. 197). Commodities from plantation business, such as indigo, sugar cane, coffee, tea, tobacco, pepper, quinine, cinnamon, silk, cochenille, or the coloring agents from insects, and other plants, were profitable. By these commodities, the Dutch Colonial Government could generate economic profit (Gonggrijp, 1938, p. 102).

In the first decade of the 18th century, indigo and coffee became the primary commodities of the Dutch East Indie, replacing the position of cardamom and paraffin. At that time, Coffee was a popular commodity due to the demand of the global market, particularly in Asian and European markets. When the price of coffee improving steadily, the Dutch financial company or Vereenigde Oostindische Compagnie (VOC) shifted the focus of economic activity into coffee trades. The shifting of trade activity decreased the volume of other commodities, such as sugar cane and tea, to become secondary commodities in the Dutch East Indie (Nagtegaal in Breman, 2014, p. 59).

Historically, the Arabica coffee was firstly planted in Indonesia circa 1696. Initially, the Arabica coffee seeds were derived from Yemen. In 1690, the Dutch Governor in Malabar smuggled the seeds from the Mocha Port in Arabia land (Saputra, 2008, p. 29). The seeds were then delivered to the representation of the Dutch Governor in Batavia through the trade route from Java, Malabar, to Ceylon (Widjaja, 2014, p. 82). The seeds were then planted in Kedawung, an area for coffee plantation near Batavia. Unfortunately, the coffee plants failed to crop due to earthquakes and floods. In 1699, the Dutch once more imported the coffee seeds from Malabar and planted it in the same area. After long experiments of cof- fee plantation, the turning point occurred in 1706 when the sample of the coffee was sent to the Netherland for extensive examination. The result of the analysis showed that the coffee planted in Java had excellent quality (Afriliana, 2018, p. 4).

In 1707 , in a short time, VOC introduced coffee plantation in Priangan, West Java. The coffee plantation in Priangan was opened as a strategy of the Dutch colonial government to compete in the global market (Knaap in Muhsin Z, 2017, p. 184). The coffee price skyrocketed, and the VOC extended the coffee plantation in other areas of Java. The result of this development was significantly higher. The Dutch East Indie became the first as well as the largest area of coffee cultivation outside of the Arab and Africa land (Samsura, 2012, p. 7). Instead of supplying the demand in the Java area, the coffees were also planted in the house yard of the Dutch or local people. Moreover, the assistants of residence also started to run their private coffee plantations in some areas of Java (Breman, 2014, p. 220). From the above description, it can be inferred Java in the 18th century became the center of coffee plantations in the Dutch East Indie.

Despite the vast extension of the coffee plantation in the 19th century, the number of coffee production in Java had not fulfilled the high demand of the global market. The reason was the Dutch Colonial Government had to compete with other coffee traders from America, South America, and Middle Africa besides the threat of disease and pest outbreaks. On top of that, the coffee from the Dutch East Indie had even lost its place in the 20th-century global market. In facing this challenge, the Dutch Colonial Government sought for the advanced coffee seeds that had a better quality to improve the production and secure their position in the global market (Creutzberg \& Laanen, 1987, p. 158). Along with this effort, the Robusta coffee, which had a strong resistance to the disease, was firstly brought in the Dutch East Indie.

Coffee plantations were also com- 
mercially developed in the western area of the Dutch East Indie. The development occurred along with the rise of the liberal party in the Netherland Parliament. For example, in the West Sumatera, the coffee plantation had been exploited by the private companies from shortly after the Dutch Colonial Government issued the Open-Door Policy in 1870 (Sabar, 2006, pp. 2-3). Meanwhile, in East Sumatera, the coffee plantation started to open in 1872 until the economic crises in 1891. In the case of East Sumatera, the coffee plantation became the alternative commodity against the tobacco crises in Deli. The private businessman and firms took a part in the establishment of the coffee plantations in West and East Sumatera (Leirissa, Ohorella, \& Tangkilisan, 2012, pp. 71-72). Besides that, the Javanese and Chinese labors also took an important role in the dynamic of the coffee plantation.

Differently from West Sumatera and East Sumatera, the coffee plantations in Aceh just started to develop in the early 20 th century. The late development of coffee plantation related to the political situation in Aceh. The Dutch Colonial Government just took over the political power in Aceh after they won the war against the Aceh, Gayo, and Alas people from 1870 to 1912. After the war, the Dutch Colonial Government implemented a capitalistic system similar to other areas in Java by opening rubber plantation in Langsa and East Aceh and also palm plantation in Tamiang.

The Dutch Colonial Government developed coffee plantation in the Gayo Highland and Takengon. However, the first initiation of the coffee plantation in Aceh was started in Tangse and Lamno areas. Because of the climate mismatch and the problem of soil fertility, those plantations failed to produce the coffee. In 1808 , four years after the end of the GayoAlas War, the Dutch Colonial Government opened the horticulture plantations that consisted of small numbers and noncommercial coffee plants in Aceh.

In the following years after the end of the Aceh War until the 1930s, the
Dutch Colonial Government and also private companies had extended their coffee plantations in some areas of Aceh and North Sumatera. The expansion of coffee plantations had brought a social change in some areas of Aceh. The social changes caused by the arrival of the contracted laborers from Java. The changes can be sensed by Gayo society, such as the shifting of livelihood from rice farmers to coffee planters. Demographically, many Javanese laborers settled in Gayo Highland after retiring from plantations. Meanwhile, the coffee industry also influenced the development of Takengon city and society.

Based on the above historical background, it can be highlighted that the Dutch Colonial Government introduced the coffee plantations in Gayo in the early 20 th century. Therefore, this article aims to reconstruct the history of coffee plantations in Gayo Highland Takengon at the time of the Dutch Colonialism era. From the authors' perspective, the history of coffee plantations in the GayoTakengon area could not be separated from the dynamic of the labors and its impact on the social and economic condition of Gayo society. Therefore, three questions presented in this research are about (1) the factors supported the establishment of the coffee plantation in Gayo Highland, (2) the development of coffee plantation at the era of Dutch colonialism, and (3) the dynamic of Javanese contracted labor in Gayo Highland Takengon.

\section{RESEARCH METHOD}

This research focuses on the critical analysis of the history of the coffee plantation in Gayo Highland Takengon at the Dutch Colonialism era from the period of the arrival in 1904 until the retreat of Dutch Colonialism in 1942. The method of historical research was used to examine the history of a coffee plantation. Methodologically, historical research could be defined as the process to critically investigate, analyze, and reconstruct the legacies of the historical event. By this method, the heritage of the past should be organized 
into a historical narrative represents the reality happened in the past. In this historical representation, the narratives should be reconstructed by emphasizing the time sequence (Gottschalk, 1975, p. 32).

Historical research consists of five stages, namely topic selection, heuristic or gathering the primary and secondary resources, verification in the form of internal and external criticism of the primary resources, interpretation, and historiography (Kuntowijoyo, 1999, p. 81). Based on those stages, firstly, the authors selected the topic of research based on the availability of primary resources and other relevant documents related to the data of Dutch Colonialism in Gayo Highland Takengon from 1904 to 1942 .

The second stage related to heuristic activity or gathering primary and secondary historical sources. The primary sources consisted of the documents and archives from the Dutch colonialism era and also the secondary source relevant to the topic such as the research or book publications about the history of the coffee plantation. The third stage is the verification process toward historical sources. The verification process aimed to validate the originality of the historical sources. This stage consisted of internal and external criticism that sought to validate the originality of the sources and its feasibility to become the source of historiography. The internal criticism aimed to verify the substance or content of the primary source by comparing it with other relevant sources. Meanwhile, the external criticism aimed to validate the originality of the primary sources by analyzing its physical appearance.

The fourth stage was the interpretation of historical data. In the interpretation stage, the data collected in the heuristic and verification stages were interpreted to generate historical facts in sequential and holistic narratives. Data classification was the most important activity in the interpretation stages. This activity was useful for examining the pattern, categorization, and historical explanation that can be used as the frame of mind. The last step was historiography that aimed to reconstruct the findings of historical research into a historical narrative.

\section{RESULTS AND DISCUSSION The driving factors of the Establishment of Coffee Plantation in Gayo Highland}

Geographically, Gayo Highland, or Takengon, is located in the middle of the Aceh mountains, which merges with Barisan Hill (Sufi \& Wibowo, 2013, p. 9). It is situated on the plateau about 1300 meters above the sea level. Takengon, as the center of Gayo Highland, has a tropical climate with high rainfall intensity and humidity. The average temperature is about 12 to 23 Celsius degree (PaEni, 2016, p. 19). In general, Gayo Highland has volcanic soil, which is quite fertile, especially around the mountain areas such as Burni Bies, Burni Telong, and Bur Kul Mountains. On the south side and west side of the volcanic soil, the area lies Peusangan river flow. At the center of the area lies Lut Tawar Lake (Melalatoa, 2003, p. 14). In those regions, the Dutch Colonial Government opened coffee plantation, tea, and merkusii pine.

Beside the lake, the water comes from the mountainous area, flowing towards the rivers (Wiradnyana \& Setiawan, 2011 , p. 2). Those rivers supplied the water for rice fields irrigation, which became the main livelihood of Gayonese before the era of the coffee plantation (Loeb, 2013 , p. 239). The water irrigation system for the rice fields also could be found in the nearby Lut Tawar Lake, where most of the people in that area worked as the rice farmer before the arrival of the coffee plantation (Setyantoro, 2012, p. 31). In the era of Dutch Colonialism, the area near Peusangan River Flow became the center of administrative activity. According to the colonial government's plan, the area near the river flows on the mountains would become the area of the coffee plantation.

The arrival of Dutch Colonialism, shortly after the end of the Gayo-Alas War (1904), had provoked political, economic, social, and cultural changes in 
Gayo Highland. Most of the colonial policies implemented in Gayo Highland related to the Dutch financial condition.

The economic policy of the Dutch Colonial Government in Aceh after the end of the Aceh War (1873-1912) was held by implementing the capitalistic system as the commercial basis of Aceh. This capitalistic system was expected to promote the economy of Aceh aligned with other areas in the Dutch East Indie (Muhajir, Yuliati, \& Rochwulaningsih, 2017, p. 64). All of the economic policies in Aceh related to the governmental policy in the Dutch East Indie, namely the Estiche Politiek. By implementing Etische Politiek, the Dutch Colonial Government introduced some policies to improve the quality of education, infrastructure development, irrigation, transmigration in the colony. Some of the policies provoked efforts to promote the economy of the people by exploring the forest for plantation areas (Wibowo, et al., 2012, p. 66).

The exploitation could not be separated from the economic condition of Aceh in 1900 when people's welfare and financial condition of the colonial government had declined because of the Aceh War. Presumably, only coffee plantations, such as in Java, could provide profits for the Dutch Colonial Government (Madjid, 2014, pp. 322-323). The profit from the coffee plantations in Java had encouraged the colonial government to open the coffee plantation outside of Java, including Aceh.

Such as in other regions of the Dutch East Indie, the colonial government started opening plantation after the political order had been stabilized in Aceh. It was needed to guarantee the safety of private companies in opening plantations in some areas of Aceh (Alfian et al., 1978, p. 113). In 1907, the Dutch Colonial Government issued some policies, both in bureaucratic and economical. One of them was the opening of rubber plantation in Langsa (Zakir, 2018, p. 140). The colonial government also opened the rubber plantation in the East area of Aceh. All of those policies were intended to secure their political power in Aceh. Those plantations also encouraged the Dutch to expand the plantation area into the deep of Aceh, such as in Takengon.

\section{The Opening of Coffee Plantation at the colonial time}

Since 1904 or shortly after the end of the Gayo-Alas' people War, the Gayo Highland achieved its position as Onderafdeeling Gayo, which was included in the area of Afdeeling Noordkust van Atjeh. At the early time of colonial rule, Oonderafdeeling Gayo was divided into two areas, namely Meegebied, which covered the areas of the lake or Gayo Lut, and Dorotstreek, which covered the land area of West Gayo. Meanwhile, the representation of the colonial government was located in Takengon under Civielgezaghebber or civil authority led by Captain Infantry P.H. Soetens (Staatsblad van Nederlandsch-Indie 1914, No. 87 and Mailr, No. 847/13). After the establishment of colonial rule, Takengon started to take part in the economic and political dynamic of the Dutch East Indie.

In fact, from 1904 to 1907, some of the Dutch officers had a common assumption about Takengon. They believe that Takengon had fertile soil with mountains and rivers flow. Thus, according to them, this area was feasible to be exploited and, therefore, should be promoted to private companies. The fertile soil was suitable to cultivate the commodities that had high values in the global market, such as coffee, tea, and quinine. Besides that, horticultural plants such as potatoes, vegetables, and fruits could also be planted in Takengon (Beets, 1934, pp. 338-339). However, only a few of the Dutch believed in this assumption. The vast majority of the Dutch had their assumption regarding Takengon that the infrastructure, especially the roads linked to the hinterland and coastal areas of Aceh, had not yet supported the economic activities in that area. Therefore, they perceived that it was impossible to cultivate coffee or other horticultural plants in Takengon. Under this contradiction, several people started to try their luck by bringing some horticultural plants to be 
planted in Takengon.

The assumption and confidence of the frontiersman had brought Takengon and Gayo Highland into a new period where coffee was firstly brought by the Dutch to Gayo Highland, especially in Takengon. The first variety brought into Takengon was Arabica Coffee, which was planted on a small scale in the Paya Tumpi area (Khalisuddin, et al., 2012, p. 61). The frontiersman of the coffee plantation in Takengon was a Dutch farmer, namely Veenhuyzen. Besides coffee, he also brought and introduced potato, another horticultural plant, in Takengon. At first, Veenhuyzen cultivated only horticultural plants such as vegetables, especially potatoes. At the same time, the small scale of coffee was planted in a limited area (Beets, 1934, pp. 339-340). Interestingly, Veenhuyzen, or also popularly known as Veenhuijzen, was the former of Assistant Residence of Dutch Colonial Government in Kutaraja, who became a farmer in Gayo Highland. According to Muhammad, Veenhuyzen's decision could not be separated from conflicts between Veenhuyzen and van Daalen, who was the Military and Civil Governor of the Dutch Colonial Government in Kutaraja. Veenhuyzen felt that the colonial government implied the rule strictly, so he sent the letter of criticism to van Daalen. Receiving the message from Veenhuyzen, van Daalen became very upset. Van Daalen accused Veehuyzen as the man who lost his loyalty and disregarded the command of his superior. Van Daalen then reported Veenhuyzen to the Governor-General of Dutch East Indies in Batavia. However, the impact of van Daalen's report was nor revealed until today (Said, 2007, pp. 313314). For Van Daalen, because of this case, he resigned from his position as the Military and Civil Governor of the Dutch Colonial Government on 4 May 1908. Presumably, in the same year, Veenhuyzen also decided to resign from his position and moved to the Gayo Highland to develop his own business. Perhaps, Veenhuyzen perceived economic prospect in Gayo Highland especially the economic prospect of the plantation. After that, Veenhuyzen started to open the plantation area and import some seeds of coffee, potato, and vegetables to Gayo Highland.

The turning point came in 1914 when the Dutch Colonial Government finished their project in building a connecting road from Bireuen, which located in the coastal area of Aceh, to Takengon, which established the hinterland area. The way had successfully attracted some private firms to enter and open plantations in Takengon. For the first time, they open coffee plantation and then continued to develop merkusii pine plantations. It could not be separated from the natural factor that the land was fertile and very suitable to cultivate Arabica coffee and tobacco (Sufi \& Wibowo, 2013, pp. 89-90). Moreover, the result of research towards the quality of Takengon's coffee had shown its excellent quality. This research proved that many areas of Takengon were suitable to be planted by Arabica coffee (Beets, 1934, p. 341). Therefore, the colonial government decided to open about 100 hectares in Blang Gele for the area coffee plantation. Today this area is the part of the Bebesan District (Melalatoa, 2003, p. 51). The name of the coffee plantation in Blang Gele was Wilhelmina Blang Gele Coffee Plantation, as it was written in the building and the entrance gate of the plantation area (Khalisuddin et al., 2012, p. 58). The name of Wilhelmina related to

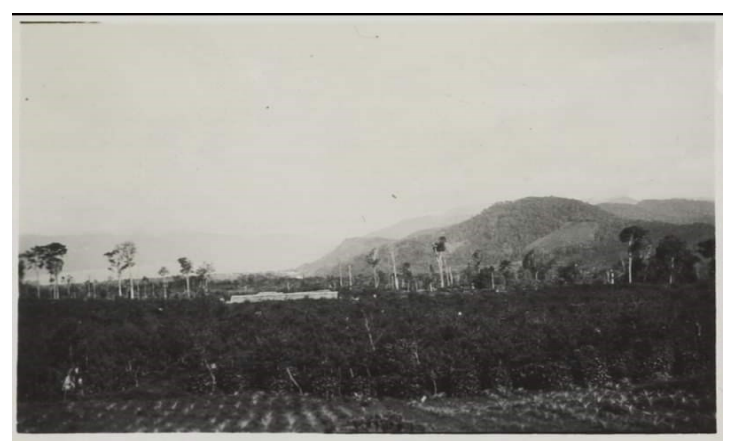

Figure 1. Wilhelmina Coffee Plantation in Blang Gele

(Source: Digital Collection Leiden University Libraries). 
the fact that the colonial government had occupied the hinterland area as the last conquered land in Aceh. As the evidence as well as a tribute to this successfulness, the plantation was then named same as the Queen of Netherland, Wilhelmina. Wilhelmina plantation became the first commercial plantation in Aceh.

Before it became a plantation area, the land of Blang Gele was the part of Zelfbesturen Reje Cek Bebesan. Land acquisition from Reje Cek Bebesan into the colonial government could not be separated from Korte-Verklaring that had a significant impact on the local law, including a permit for land use. Consequently, from 1904 to 1925 , the colonial government had a full license to use the land in Blang Gele. Moreover, the area of Blang Gele was uninhabited land and far from the settlement of Cek Bebesen. Those areas had fertile soil, and some of them were just fields covered with Gele trees (ficus racemose) or fig trees. Fig trees lived in a humid area near river flow. Therefore, the colonial government perceived that the area was suitable for coffee plantation. Since then, the region is popularly known as Blang Gele.

In 1920, the colonial government opened other coffee plantation areas in Pondok Baru and Silih Nara or Burni Bius (PaEni, 2016, p. 37). In Wih Bakong Village, near those areas, the colonial government also opened coffee plantation, but the information about the area of the plantation was unknown. Meanwhile, in Wih Porak, not too far from Silih Nara, the colonial government also established a coffee factory as the place to mill and desiccate the coffee. The area for dehydrating the coffee was about 5.400 meter2. Besides of desiccating area, they also built a private pool as a place to peeling, ripening, cleaning, and drying coffee beans. The factory also had complete facilities such as the bathroom, waterwheel, and conduits (Susilowati, 2008, p. 38). The establishment of the factory was inseparable from the success of the Wilhemlima Blang Gele Coffee Plantation. In the following years, the colonial government

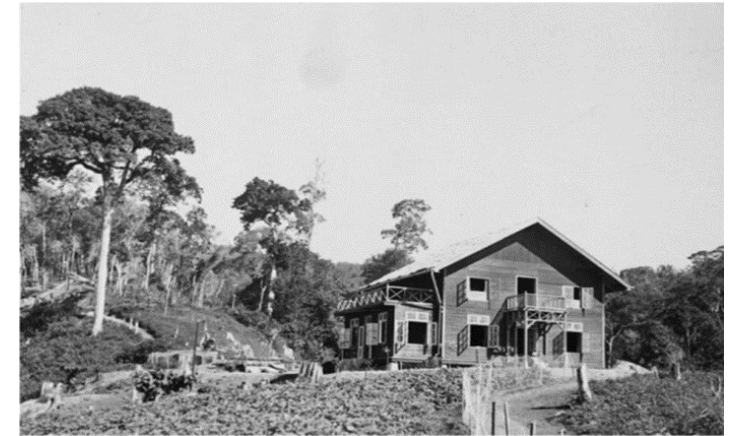

Picture 2. The Veenhuijzen's house in Paya Tumpi

(Source: Digital Collections Leiden University Libraries).

expanded the area of a coffee plantation in other areas of Aceh. The area of Gayo Highland increasingly attracted private companies to open coffee plantation, and it could generate profits for the colonial government.

Besides of Pondok Baru and Silih Nara Coffee Plantations, the private firms also opened coffee plantations in the area of Bandar Lampahan. The increasing number of coffee plantations in Gayo Highland came from Veenhuijzen efforts as the frontiersman of the coffee plantation in Gayo Highland. In 1921, the family of Veenhuijzen expanded the area of the coffee plantation in Paya Tumpi and opened a private company named Paya Tumpi (Beets, 1934, p. 341). Some hills in PayaTumpi were opened as the area of the coffee plantation. Besides that, Veenhuijzen also planted other horticultural plants. To facilitate and expedite his business, Veenhuijen also built a house building, which also served as his home with his wife and three sons.

Other areas in Aceh were unsuitable for coffee plantation and dominated by uyem or merkusii pine. The merkusii pine grew wild in some part of Takengon. From 1925 to 1926, the Dutch Colonial Government began planting the pine intensively. For the first time, pine was only planted in five areas that were Lampahan, Ratawali, Burni Telong, Pante Raya, and Bidin or Blang Jorong. Circa 1928, the Dutch Colonial Government opened a 


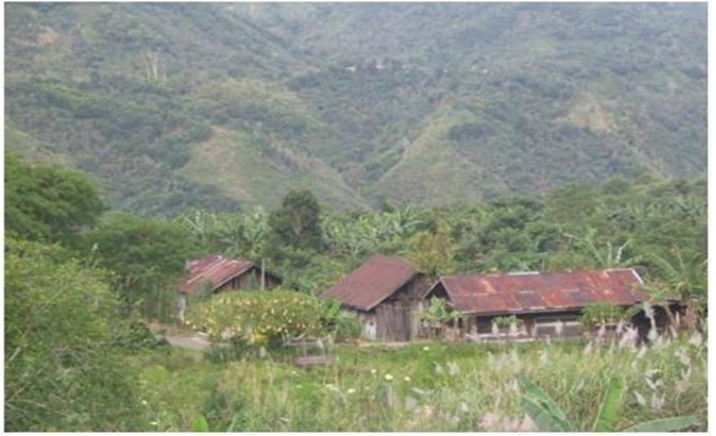

Figure 3. The remains of the coffee factory in Weh Pesam Village Source: Sutrisna (2007, p. 16)

pine plantation in Isaq and around Lut Tawar Lake. In 1930, the pine plantation covered about 49.600 hectares (Walad, 1971, p. 28). Lampahan, for the first time, was only focused as the area for cultivating the merkusii pine. The seeds were then planted in Blang Jorong (today this area is the part of Bener Meriah Regency), Laut Tawar Lake, and Isaq or Linge (Khalisuddin et al., 2012, p. 60). Since 1926 , some of the local people had realized the benefits of pine mercusi as the raw material of asphalt and paper. The local people used pieces of merkusii pine as the torch and ignited the fire before kerosene (Rusdi, 2011, p. 38). The functions of merkusii pine also encouraged some private firms to invest their money for coffee plantation. Moreover, many labors, who originally came for merkusii pine plantation, moved to work for coffee plantation managed by the Dutch or private firms.

Entering the early 1930s, the Dutch Colonial Government expanded the area of Blang Gele coffee plantation to became 125 hectares. In the same year, the colonial government also opened a new coffee plantation in Bergendal, but no infor- mation about the area. Along with the development of the coffee plantation in Blang Gele, the colonial government built a factory for coffee processing and the houses for laborers. After the enhancements of those plantations were finished, the colonial government continued to expand the area of the coffee plantation into the area of Redines, Reronga, and Bandar Lampahan. The area of Bandar Lampahan and Reronga was located lower than in other areas. Thus the variety of Robusta Coffee was suitable to be planted in those areas (Khalisuddin et al., 2012, p. 58). To link the coffee production and distribution among the areas of coffee plantation and minimize the financial expenditure, the colonial government built another coffee factory in Lampahan area in 1931. Perceiving from its facilities, this factory was bigger than Wih Porak and Blang Gele coffee factories.

At that time, the desiccated coffee was carried by private transportation services or the local people to Kutaraja or even to the East Aceh. Besides coffee, other commodities such as tea and resin also became the export commodities. The Report of Aceh Economic Development from 1923 to 1938 informed that the products of Arabica and Robusta coffee plantations also came from smallholder plantations owned by local people. The reports also mentioned three export commodities from Gayo, especially coffee from Takengon. Three commodities of Gayo can be seen in table 1.

The economic depression in 1930 is a highly impacted plantation business in Indonesia, especially coffee and sugar plantations. On the other side, other com-

Table 1. The amount of coffee, tea, and resin or pine exports from 1925 to 1938

\begin{tabular}{lllllll}
\hline Varieties & \multicolumn{7}{l}{ The amount of plantations export, year/tonnage } & Guldens per \\
\cline { 2 - 6 } & 1925 & 1929 & 1933 & 1937 & 1938 & $\mathbf{1 9 3 8}$ \\
Coffee & & 8 & 9 & 246 & 207 & 83.000 \\
Tea & - & - & - & - & 260 & 185.000 \\
Resin & 293 & - & - & 254 & 189 & 22.000 \\
\hline
\end{tabular}

Source: (Stockum \& Zoon, 1944) 
modities such as tea, rubber, and tobacco increased significantly (Leirissa et al., 2012, p. 70). The crises from 1930 to 1933 also had a high impact on the coffee plantations in Gayo Highland. The number of coffee productions and export from 1925 to 1928 could not be identified. Meanwhile, in 1929, the amount of coffee export was about 8 tons.

Moreover, from 1930 to 1933 , at the peak of economic depression, coffee production did not improve significantly and only reached 9 tons. The decrease in the number of export commodities was not only caused by economic depression. From 1925 until 1933, the colonial government focused on expanding the area of coffee plantation, tea, and resin. As a result, in 1937, the production of coffee plantation increased significantly, with the amount of export reached 246 tons, even though the amount decreased a year later to be 207 tons. According to the Dutch Economic Report, the colonial government took a profit of about $f 83.000$. However, there are no documents left to inform the export data of plantations after the year 1938.

In 1939, the political situation of the Dutch East Indie became unstable due to World War II. In the early of World War II, the Dutch East Indie became the main target of the Japanese Army to be conquered. Japanese Army perceived the Dutch East Indie as a strategic land to support its military activity in Southeast Asia. The threat of the Japanese Army continued until the fall of the Dutch Colonial Government in Dutch East Indie in 1942 (Oktorino, 2013, pp. 27-30); Anshori, 2010, pp. 119-120). Therefore, since the deployment of the Japanese Army in Aceh, the unfatigued local armies helped the Japanese military until the Dutch army surrendered and left Aceh on 28 March 1942 (Sufi, 2001, pp. 35-36). Because of that, during World War II, the coffee plantations entered the darkest age. Many koffie onderrneming wrecked directly or indirectly by the wars (Khalisuddin et al., 2012, p. 69). After the independence era, many plantations revived under the control of local people. The coffee plantation managed by the Dutch started to switch to the local authorities, such as the local government or small part of them led by the local people.

\section{The labors of Gayo Highland Coffee Plantation}

During the reign of the colonial government, there was a colonial term that today been known as transmigration. Colonialism itself only began in 1905 after the implementation of the Ethics Policy in Dutch East Indie. In this case, the coming of Javanese labor in Aceh related to the term colonialism. As mentioned in Junaidi's research (2012, p. 56), there were three driven factors of colonial policy to bring Javanese laborers outside of Java Island. First, the Dutch colonialism tried to imply one of point of Ethische Politiek or politic of reciprocation. Second, the demographic problem in Java made the population density had made demographic problems in Java Island. Third, the need for the labor to operate many plantations and factories managed by the Dutch Colonial Government and private firms outside of Java Island. Conjecturally, the coming of the worker from Java to Gayo Highland could not be separated from the need for human resources to operate plantations owned by the Dutch or private firms.

The plantations at the era of Dutch colonialism always related to the labor problem or in local terminology known as kuli or coolie. If the number of laborers was insufficient, then the plantations could not generate profits. To solve this problem, the owner of private firms usually enforced the rules to boost the benefit, such as they select the laborers who were inlander or indigenous people. Most of the labor had a low education degree, and the firms paid them with low wages. By this mechanism, the firms economically could get more significant profits (Gordon, 1982 , p. 174). The benefits of the plantations depended on the hand of Javanese laborers. For the Dutch, besides the low wage, poor labor would become the worker for private and Dutch firms on their 
own (Atmosudirdjo, 1984, pp. 178-179). Therefore, the laborers took an essential role in the expansion and the development of plantation at the era of the Dutch colonialism.

In the case of Gayo Highland, it can be said that the labor who were brought in to Gayo perhaps came later in comparison with other areas in Aceh. The reason was the establishment of commercial plantations just started in 1918. In early 1917, the colonial government had a plan to bring Chinese laborers from the outside of Aceh. However, the colonial government assumed that the Chinese laborers were inexperienced in planting the coffee. Therefore, they recruited Javanese laborers, who already had experienced planting coffee in Java. Besides that, the Javanese laborers were also known for their diligence and tenacity.

Consequently, only a few Chinese labors were employed as a trader or as a worker building the roads. As mentioned by Handinoto, most of the Chinese in the time of colonialism only took a role as a retailer and broker. Chinese man took a position as a broker for local people. The Chinese broker bought the farmer commodities from local people and sold that to European wholesalers (Handinoto, 2015 , p. 85). Another reason for taking the Chinese and Javanese laborers was the fact that the local people were still unready to be employed in European firms after the end of the Aceh War.

Consequently, only a few of the European firms recruited and engaged the local people (Dick, Houben, Lindblad, \& Wie, 2002, pp. 103-104). On the other hand, the local people believed that infidel organized European firms. Thus, they were forbidden to work for the Europeans.

In 1918, the colonial government brought in the Javanese labors directly from Java Island. Most of the labor was poor and tied up by the contract system, namely contractaten. They were employed to open areas for coffee plantations in Blang Gele. The contract system referred to the Staatsblad 1915. Based on the contract, the laborers only bound with the company for three years. After their contract period expired, the laborers had two choices. First, the laborers could go back to their homeland with repatriation costs borne by the colonial government. Second, the laborers could stay in Aceh with some provisions. The provisions stated that the laborers should extend their contracts. They would receive the same wages as they get in the first year. The laborers were work for Wilhelmina Blang Gele Coffee Plantation. Unfortunately, there was no document informing the number of laborers brought in to Blang Gele at that time. Perceiving from the area of plantation and the division of labors from opening, teaching, and nursing the plants, it could be assumed that about hundreds of people were brought in to Blang Gele at the colonial period.

Entering the early 1920s, the colonial government continuously brought in the contracted laborers from Java. The Javanese labors were called as Jawa Kontrak (Javanese under the Contract) or Jawa Kolonisasi (Java Colonialism). They were employed in some plantation areas such as the pine plantation in Lampahan and Isaq, the coffee plantation that was just opened in Pondok Baru, and the coffee plantation in Silih Nara. Some of the laborers were employed in the tea plantation in Redelong and Janarata (PaEni, 2016, p. 37). The term "colonialism" for the Javanese labors could not be separated from the colonial government's term to refer the laborers from Java as the process of colonization rather than transmigration (Kementerian Desa, Pembanguan Daerah Tertinggal dan Transmigrasi R.I, 2015, p. 1). The laborers were brought in to fulfill the needs of the labor of plantation due to the expansion of the coffee plantation area after 1920. Instead of working for coffee plantations, the laborers were also employed for tea plantations and merkusii pine plantations.

Some of the coffee and pine plantations, such as Silih Nara and Burni Bius coffee plantations, were owned by a German company. Some of the German people were employed on that plantations as 
the administrators (Pinan, 2003, p. 56). Moreover, from 1925 to 1926, some merkusii pine plantations in Lampahan, Ratawali, Burni Telong, Panti Raya, and Bidin, were exploited intensively. In 1928, the area of merkusii pine plantation was expanded by opening some areas in Isaq and Lut Tawar Lake (Walad, 1971, p. 28). The expansion of coffee and pine plantations forced the colonial government to bring in more laborers from Java. Sometimes the laborers of pine plantations were mobilized to work in coffee plantation for an unacceptable reason, such as problems with coworkers.

In 1937, the colonial government brought in more laborers from Java. The laborers were employed to work for merkusii pine plantations in Atu Kul Isaq areas. The Javanese laborers came from different ages. Sometimes they came with their families (PaEni, 2016, p. 41). Most of the labors came from Central Java, Yogyakarta, East Java, and West Java (Wibowo et al., 2012). Precisely, this labor was the family workers who deserve to be called Javanese Colonization. Commonly, there was a division of labor among workers in which age would determine the weight of the laborers. Most of the youngers would be employed in pine plantations while for the labor, both men or women, aged above 35 would be employed in coffee or tea plantations. These labors were usually bound by a contract system. At the beginning of the work period, workers might sign an agreement containing the duration of the contract, wages, place of residence, insurance, health, and penalties for violations. Many of the contracts referred to Staatsblad 1911 and Staatsblad 1915 . According to Manurung, in North Sumatra plantations, if there were workers who neglected their duties, they would be captured by the opas or security of the plantation. It was under the work agreement that the worker had signed. Usually, the foremen would give punishment to the laborers (Manurung, 1977, p. 44). Penalties for violations had also been applied to contract laborers in Gayo Coffee Plantations.

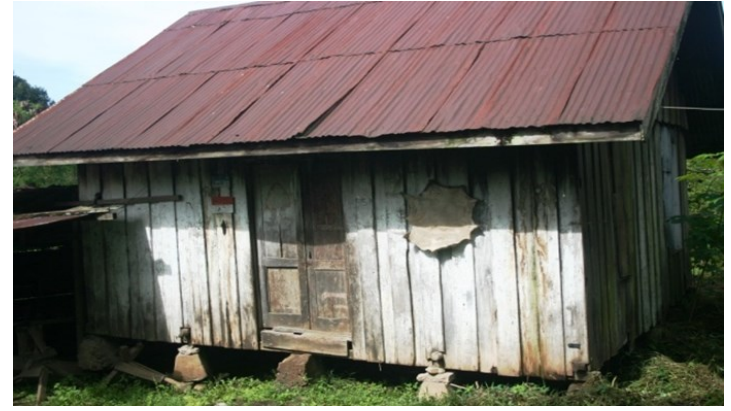

Figure 4. The settlement for Javanese Labors

Source: www.lintasgayo.com

Most of the Javanese laborers were young couples with a maximum age of 25 years. The colonial government believed that the physical condition of the laborers at that age was in their peak performance. Besides that, many labors age above 25 years old and married laborers. However, the number of married laborers was fewer than the number of young couples. In this case, in every job, the policy of age limitation was essential. Besides, other things that were considered by the colonial government was the level of wages for work and health. So that in every plantation, a kind of clinic was provided with free or free medical treatment (PaEni, 2016, p. 41).

Once a month, the Dutch held performing arts like ketoprak or Javanese theater to entertain the laborers. The gambling place occurred nearby the plantation area (Khalisuddin et al., 2012, p. 58). The gambling place was usually made without permission from the owner of the plantation. Commonly, a large plantation foreman provided both as a security guard. Thus, he had a chance to give consent or even held the gambling place. The gambling place brought a negative impact on the life of laborers. Most of the laborers' salaries were spent on gambling places. It had made most of the laborers had to extend their contracts in plantation because they are in debt. The laborers had to borrow money from the foreman and the Chinese financiers. If the laborers were unable to pay off the debt, then they could pay by working outside working hours on the plantation. Usually, the laborers were told 
to hoe and open a large plot of land for the foreman. After the contract period ends, most of the laborers were not return to their homeland and stayed in the nearby area of plantation. With hard work habits, discipline, and willingness to try their farm, the laborers could run the wheel of life by opening their coffee and vegetable plantations on a small scale (PaEni, 2016, pp. 43-44). The Javanese laborers kept their tradition by performing traditional arts in their settlements, such as Kuda Lumping or horse art performance, Ludruk or east Java theater, and Wayang or Shadow puppet performance (Sitanggang, Tanjung, \& Pertiwi, 1994, p. 4).

Regarding the level of welfare of the laborers, it was indeed slightly better than the previous time in Java or their homeland. Many labors whose economic level was sufficient ultimately choose to live in Gayo Highlands. However, many laborers were forced to stay because, in 1940, the political situation in the Dutch East Indie was unstable, especially during the time of World War II. During the war, the laborers had to stay in Aceh. These laborers eventually established settlements at several points in Aceh, such as in the area of Pondok Gajah, Pondok Sayur, Karang Rejo, and the other regions of Aceh. In the next period, these laborers are called the Javanese, who born in Sumatera.

\section{CONCLUSION}

Geographically, the area of GayoTakengon Highland is the plateau flanked by hills and mountains. The area consists of volcanic and fertile soil. This geographical factor encouraged the Dutch Colonial Government to run a capitalist economic system that had previously been applied in other areas of Aceh, such as Langsa and North Aceh.

From 1904 to 1907, a few of the Dutch had an assumption that $\mathrm{Ga}$ yoTakengon and the nearby areas were suitable to cultivate the plants. They also believed that private companies could invest their capital in Takengon. On the other side, most of the Dutch argued the assumption because Takengon was still iso- lated. There was no connecting road that linked Takengon with the Aceh's coastal areas such as Bireuen. Without roads, it is impossible to distribute the crops to the global market. However, a small number of Dutch were convinced that the Takengon area could be profitable such as other regions like Langsa and East Aceh. This belief had led some Dutch to open horticultural plantations. In 1908, for the first time, the Dutch brought several horticulture plants such as coffee, tea, and quinine plants to Takengon. Firstly, the plantation was only opened with a limited area and a variety of horticultural plants. The first area that was used as a coffee plantation was the PayaTumpi area (now included in the Kebayaan District).

The success of plantation and horticultural crops, especially coffee in PayaTumpi, had encouraged the Dutch Colonial Government to open more extensive coffee plantations. It was supported by the availability of a highway that connects Takengon with Bireuen, the coastal area Aceh. In 1918, a new Arabica coffee plantation was opened in the BlangGele area (now part of the Bebesen District) with an area of 100 hectares. To prove to the Dutch queen that after 1912 Aceh had entirely conquered by the Dutch, the plantation was given the name as the Wilhelmina BlangGele Coffee Plantation. The plantation became the first commercial plantation in Gayo Highlands.

The expansion of the Dutch Colonial Government was not stopping after the establishment of the Wilhelmina BlangGele Coffee Plantation. In 1920, the colonial government reopened coffee plantations in the PondokBaru and Silih Nara areas. In the following year, from 1921 to 1931, the colonial government continued to expand coffee plantations, both Arabica coffee and Robusta coffee in more areas such as the Silih Nara, Redines, Reronga, and Lampahan. The development of coffee plantations had also been followed by the inclusion of several private companies that had participated in opening coffee plantations in Takengon, such as the Silih Nara and Bergendal Coffee Plantations. 
Because of that, the Dutch also had to establish factories for coffee processing such as in the WihPorak, BlangGele, and Lampahan Coffee Factories.

In running its business, especially coffee plantations, the Dutch brought contract laborers from Java. In 1918, the first contract laborers were brought in to the Gayo Highland, especially in Takengon. These laborers were then called the Java Contract or the Java Colonization. Most of the laborers were poor, low educated, or even uneducated people. In terms of age, most of the laborers were still relatively young, also though there were married laborers who brought their families. The rules that apply to the workers referred to the statutes of 1911 and 1915. In addition to getting paid, labors also get facilities such as houses, health facilities, and other facilities.

In 1940, due to World War II, the arrival of the Japanese army, and the fall of the Dutch Colonial power, many contract laborers could no longer return to Java. They had to choose to stay and continue their life by establishing several villages such as Pondok Gajah, PondokSayur, KarangRejo, and other communities. Some of them were successful in developing private plantations based on their experiences and skills as laborers in the Dutch plantation. It is not surprising that in the further periods, they also opened plantations, especially coffee and horticulture plants in the area of Gayo Highland Takengon.

\section{REFERENCES}

Afriliana, A. (2018). Teknologi Pengolahan Kopi Terkini. First Edition. Yogyakarta: Group Penerbitan CV Budi Utama.

Alfian, T. I., Ibrahim, M., Arifin, M., Sulaiman, N., Sufi, R., Ahmad, Z., \& Ambary, H. M. (1978). Sejarah Daerah Provinsi Daerah Istimewa Aceh. Jakarta: Departemen Pendidikan dan Kebudayaan.

Anshori, M. J. (2010). Sejarah Nasional Indonesia Masa Prasejarah sampai Masa Proklamasi Kemerdekaan. Jakarta: PT Mitra Aksara Panaitan.

Atmosudirdjo, P. (1984). Sejarah Ekonomi Indonesia dari Segi Sosiologi Sampai Abad XIX.
Jakarta: IKAPI.

Beets, K. T. (1934). Het Gajo-Land "Takengon". Amsterdam.

Breman, J. (2014). Keuntungan Kolonial dari Kerja Paksa: Sistem Priangan Tanam Paksa Kopi di Jawa. Jakarta: Yayasan Pustaka Obor Indonesia.

Creutzberg, P., \& Laanen, J. T. M. van. (1987). Sejarah Statistik Ekonomi Indonesia. Jakarta: Yayasan Pustaka Obor Indonesia.

Dick, H., Houben, V. J. H., Lindblad, J. T., \& Wie, T. K. (2002). The Emergence of $A$ National Economy: An Economic History of Indonesia, 1800-2000. Honolulu: University of Hawai'i Press.

Gonggrijp, G. (1938). Schets eener Economische Geschiedenis van Nederlandsch-Indie (Fourth Edition). Haarlem: De Erven F. Bohn N.V.

Gordon, A. (1982). Indonesia, Plantation and The PostColonial Mode of Production. Journal of Contemporary Asia, 2(12), 168187.

Gottschalk, L. (1975). Mengerti Sejarah: Pengatar Metode Sejarah. Translated by N. Notosusanto. Depok: Yayasan Penerbit Universitas Indonesia.

Handinoto. (2015). Perkembangan Kota di Jawa Abad XVIII Sampai Pertengahan Abad XX Dipandang dari Sudut Bentuk dan Struktur Kotanya. Yogyakarta: Penerbit Ombak.

Junaidi. (2012). Perkembangan Desa-Desa Eks Transmigrasi dan Interaksi dengan Wilayah Sekitarnya serta Kebijakan Kedepan (Kajian di Provinsi Jambi). Bogor: Institut Pertanian Bogor.

Kementerian Desa, Pembanguan Daerah Tertinggal dan Transmigrasi R.I Direktorat Jenderal Penyiapan Kawasan dan Pembangunan Pemukiman Transmigrasi, Direktorat Bina Potensi Kawasan Transmigrasi, T. (2015). Transmigrasi Masa Doeloe, Kini dan Harapan Kedepan. Jakarta: Direktorat Bina Potensi Kawasan Transmigrasi.

Khalisuddin, Setyantoro, A. S., Gayosia, A. P., Bathin, W. R., \& As, N. B. (2012). Kopi dan Kehidupan Sosial Budaya Masyarakat Gayo. Edited by Jamhuri. Banda Aceh: BPNB Aceh.

Kuntowijoyo. (1999). Pengantar Ilmu Sejarah. Third Edition. Yogyakarta: Yayasan Bentang Budaya.

Leirissa, R. Z., Ohorella, G. A., \& Tangkilisan, Y. B. (2012). Sejarah Perekonomian Indonesia. Yogyakarta: Ombak. 
Loeb, E. M. (2013). Sumatera: Sejarah dan Masyarakatnya. Yogyakarta: Ombak.

Madjid, M. D. (2014). Catatan Pinggir Sejarah Aceh: Perdagangan, Diplomasi, dan Perjuangan Rakyat. Second Edition. Jakarta: Yayasan Obor Indonesia.

Manurung, D. (1977). Sejarah Kebangkitan Nasional Daerah Sumatera Utara. Jakarta: Departemen Pendidikan dan Kebudayaan.

Melalatoa, M. J. (2003). Gayo: Etnografi Budaya Malu. Jakarta: Yayasan Budaya Tradisional dan Pariwisata.

Muhajir, A., Yuliati, D., \& Rochwulaningsih, Y. (2017). Industrialisasi dan Eksistensi Kota Langsa Pada Era Kolonial, 19071942. Paramita: Historical Studies Journal, 27(1), 63-76

Muhsin, M. (2017). Produksi Kopi di Priangan Pada Abad Ke-19. Paramita: Historical Studies Journal, 27(2), 182-194.

O'Malley, W. J. (1988). Sejarah Ekonomi Indonesia. Jakarta: LP3ES.

Oktorino, N. (2013). Konflik BersejarahRuntuhnya Hindia Belanda. Jakarta: PT Elex Media Komputindo.

PaEni, M. (2016). Riak di Laut Tawar: Tradisi dan Perubahan Sosial di Gayo Aceh Tengah. Yogyakarta: Ombak.

Pinan, A. R. H. A. (2003). Pesona Tanoh Gayo. Aceh Tengah: Pemerintah Kabupaten Aceh Tengah.

Rusdi, P. (2011). Pacu Kude: Permainan Tradisional di Dataran Tinggi Gayo. Banda Aceh: Balai Pelestarian Sejarah dan Nilai Tradisional.

Sabar. (2006). Kebijakan Besar Pemerintah Belanda di Sumatera Barat. Padang: Andalas University Press.

Said, H. M. (2007). Aceh Sepanjang Abad. Volume II. Medan: Harian Waspada Medan.

Samsura, D. (2012). Ngopi Ala Barista. Jakarta: Penebar Plus.

Saputra, E. (2008). Kopi: Dari Sejarah, Efek Bagi Kesehatan Tubuh, \& Gaya Hidup. Yogyakarta: Harmoni.

Setyantoro, A. S. (2012). Nelayan Depik di Dataran Tinggi Gayo. Banda Aceh: Balai Pelestarian Sejarah dan Nilai Tradisional.
Sitanggang, H., Tanjung, Z., \& Pertiwi, W. (1994). Kehidupan Masyarakat Pujakesuma di Sumatera Utara. Jakarta: Departemen Pendidikan dan Kebudayaan.

Staatsblad. (1911). Staatsblad 1911.

Staatsblad. (1915). Staatsblad 1915.

Staatsblad van Nederlandsch-Indie 1914. (n.d.).

Stockum, W. P. van, \& Zoon. (1944). Overzicht van De Economische Ontwikkeling van Atjeh Sedert de Pacificatie (Tijdperk 1923-1938). Den Haag: Samengsteld in Opdrachat van Atjeh-Instituut Door.

Sufi, R. (2001). Sejarah Perkeretaapian di Aceh. Banda Aceh: Balai Kajian Sejarah dan Nilai Tradisional.

Sufi, R., \& Wibowo, A. B. (2013). Gayo: Sejarah dan Legenda. Banda Aceh: Badan Arsip dan Perpustakaan Aceh.

Susilowati, N. (2008). Berita Penelitian Arkeologi, No. 19: Situs dan Objek Arkeologi di Kabupaten Aceh Tengah, Provinsi Nanggroe Aceh Darussalam. Medan: Balai Arkeologi Sumatera Utara.

Sutrisna, D. (2007). Kopi: Komoditas Unggulan dari Masa Kolonial di Dataran Tinggi Gayo Kabupaten Aceh Tengah. Jurnal Berkala Arkeologi Sangkhakala, 10(20), 1118.

Walad, Y. (1971). Monograf Daerah Kabupaten Atjeh Tengah. Banda Aceh: Universitas Syiah Kuala.

Wibowo, A. B., Sufi, R., Zulfan, Yulsafli, \& Waryanti, S. (2012). Akulturasi Budaya Aceh Pada Masyarakat Jawa di Kota Langsa. Banda Aceh: Balai Pelestarian Nilai Budaya Banda Aceh.

Widjaja, R. (2014). Warung Tinggi Coffee: Kopi Legendaris Tertua di Indonesia, Sejak 1878. Jakarta: Bhuana Ilmu Populer.

Wiradnyana, K., \& Setiawan, T. (2011). Gayo Merangkai Identita. First Edition. Jakarta: Yayasan Pustaka Obor Indonesia.

Anonymous. 2019. The settlement for Javanese Labors. In Lintasgayo. Retrieved April 01, from http:// www.lintasgayo.com $/$

Zakir, M. (2018). Perubahan Pemerintahan Mukim di Langsa pada Era Kolonial, 1907-1942. JUPSI: Jurnal Sejarah Peradaban Islam, 2(2), 134-142. 